\title{
Students' Intentions to Use Distance Education Platforms: An Investigation into Expanding the Technology Acceptance Model through Social Cognitive Theory
}

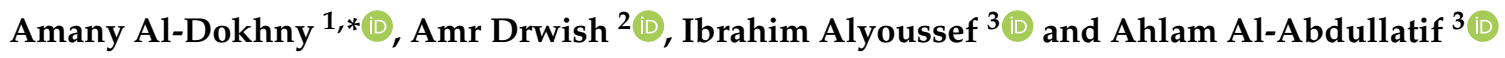 \\ 1 Educational Technology Department, College of Specific Education, Ain Shams University, Cairo 11566, Egypt \\ 2 Educational Technology Department, College of Education, Helwan University, Cairo 11795, Egypt; \\ AMR_DARWISH@edu.helwan.edu.eg \\ 3 Curriculum and Instruction Department, College of Education, King Faisal University, Al-Ahsa 31982, Saudi \\ Arabia; ialyoussef@kfu.edu.sa (I.A.); aalabdullateef@kfu.edu.sa (A.A.-A.) \\ * Correspondence: aeldokny@kfu.edu.sa; Tel.: +966-568-149225
}

check for updates

Citation: Al-Dokhny, A.; Drwish, A.; Alyoussef, I.; Al-Abdullatif, A. Students' Intentions to Use Distance Education Platforms: An Investigation into Expanding the Technology Acceptance Model through Social Cognitive Theory. Electronics 2021, 10, 2992. https:// doi.org/10.3390/electronics10232992

Academic Editor: Christos J. Bouras

Received: 31 October 2021

Accepted: 28 November 2021

Published: 1 December 2021

Publisher's Note: MDPI stays neutral with regard to jurisdictional claims in published maps and institutional affiliations.

Copyright: (c) 2021 by the authors. Licensee MDPI, Basel, Switzerland. This article is an open access article distributed under the terms and conditions of the Creative Commons Attribution (CC BY) license (https:/ / creativecommons.org/licenses/by/ $4.0 /)$.

\begin{abstract}
The current study aims to investigate the crucial factors that influence the behavioral intentions of students to use distance education platforms $\left(\mathrm{DEP}_{\mathrm{S}}\right)$. The tested Davis Expanded Technology Acceptance Model (TAM) was applied with Bandura's social cognitive theory (SCT). This study included 453 university students using $\mathrm{DEP}_{\mathrm{s}}$ in the Kingdom of Saudi Arabia. A quantitative approach was adopted, and the results revealed that both perceived ease of use and usefulness have a strong influence on student intentions to use $\mathrm{DEP}_{\mathrm{s}}$. Observational learning and computer self-efficacy also strongly influence perceived ease of use, and learner control with scaffolding was shown to significantly influence perceived usefulness. Moreover, the results confirmed the significant effect of perceived ease of use on perceived usefulness. Accordingly, the results provide valid support for an integrated framework including both TAM and SCT to understand how students may accept $\mathrm{DEP}_{\mathrm{s}}$ to improve their educational performance. This integration would help the decision-makers who are responsible for managing these platforms to assess the real needs of students at all higher education institutions.
\end{abstract}

Keywords: technology acceptance model (TAM); social cognitive theory (SCT); distance education platforms $\mathrm{DEP}_{\mathrm{s}}$; structural equation modeling; student behavioral intentions; higher education; Saudi Arabia

\section{Introduction}

Currently, $\mathrm{DEP}_{\mathrm{s}}$ have become widespread in their use in both learning and training, especially in higher education; in many ways, they have become more sensible and usable than traditional education methods. $\mathrm{DEP}_{\mathrm{s}}$ have been considered in many research works since they allow us to address the most common problem in higher education: providing full and equal access to learning for all students who are at the same learning level. Moreover, $\mathrm{DEP}_{\mathrm{s}}$ enable flexibility in the learning process in terms of the educational schedule, the work that students can perform, and the delivery of assignments [1,2]. Furthermore, $\mathrm{DEP}_{\mathrm{s}}$ can provide students with a thoughtful, interactive, representative, and collaborative learning environment [3] while also saving on costs, time, and effort. DEPs also encourage students to develop their learning and knowledge creation skills in both cooperative and collaborative settings [4]. In $\mathrm{DEP}_{\mathrm{s}}$, students can spend their time learning in a more efficient way, and alternative class material is more widely available and useable [5]. $\mathrm{DEP}_{\mathrm{s}}$ are based on the student-centered learning approach, as the tutor takes on the role of the guider and facilitator while the students are immersed in self-learning or peer-to-peer activities. By using the student-centered approach in $\mathrm{DEP}_{\mathrm{s}}$, the students can frequently follow up with their progress online [2]. 
The concept of the $\mathrm{DEP}_{\mathrm{s}}$ is based on several programmed procedures that have been conventionally situated at universities for students who are separated geographically and who are rarely on campus; these procedures have allowed educational organizations to enhance their services in terms of quantity and quality [6]. Today, the implementation of $\mathrm{DEP}_{\mathrm{S}}$ is no longer limited to serving students with geographical challenges, as they have also been used during the recent COVID-19 pandemic, allowing students to move forward along their educational paths despite these compelling circumstances [7].

The goal behind the use of a $\mathrm{DEP}_{\mathrm{s}}$ is to raise the cognitive skills and efficiency of students in terms of either education or training [8], and to achieve this, students must be encouraged to use them. Both learner satisfaction and intent play a critical role in measuring the ability of these platforms to achieve these goals [9]. In general, we find that both satisfaction and behavioral intention with respect to e-learning have been discussed in a wide range of educational studies [10-13]. At the same time, we found a gap in those studies, insofar as the extent to which student intentions to use $\mathrm{DEP}_{\mathrm{s}}$ have not been attended to. Furthermore, many research works have employed multi-theoretical models to assess student intentions to use a variety of e-learning systems $[9,11,14,15]$, but there is still a scarcity in the discussion of theoretical models, specifically for $\mathrm{DEP}_{\mathrm{s}}$. In addition, there is an urgent need to determine the critical factors for success with regard to the use of $\mathrm{DEP}_{\mathrm{s}}$ in higher education, especially in terms of understanding the factors affecting their ease of use, which of course is also an issue of their desired usefulness. It is also important to consider that $\mathrm{DEP}_{\mathrm{s}}$ are based on social interaction [6].

The present study examines four external factors arising from social cognitive theory (SCT): observational learning, learner control with scaffolding, self-regulation, and computer self-efficacy, which are related to the technology acceptance model (TAM) variables of perceived ease of use, perceived usefulness, and intention to use $\mathrm{DEP}_{\mathrm{s}}$. The importance of this study lies in its focus on examining and analyzing the suggested theoretical model to help us understand the most suitable strategies and approaches to activate $\mathrm{EDP}_{\mathrm{s}}$ in higher education. The findings will allow the administrators of $\mathrm{DEP}_{\mathrm{s}}$ to obtain a deeper understanding of the critical factors that affect student intentions to use $\mathrm{DEP}_{\mathrm{s}}$ and ac to apply suitable strategies accordingly to achieve better outcomes in these learning settings.

\section{Theoretical Model and Hypothesis}

In recent years, the information technology (IT) field has continued to undergo changes in terms of hardware and software, changes that usually cost a lot of money for learners, instructors, and institutions. Thus, organizations, especially those in higher education, need to investigate student willingness to use certain technologies before providing them as an alternative to traditional educational methods [16]. The TAM model has been widely adopted by both researchers and practitioners in predicting and explaining student intentions to use any e-learning system via perceived ease of use and perceived usefulness [16-20]. Therefore, the present study also uses the TAM model to investigate student intentions to use DEPs.

The SCT seeks to explain how students behave and perform in different learning situations to acquire knowledge in a social framework. Human behavior is a product of the environment and our social interactions with others, some of whom are considered role models [21]. At the same time, these behaviors are a driver and influence towards more desired behaviors in this environment. Accordingly, learning occurs via many behavioral patterns through the process of observation and modeling [21-23]. Observational learning is based on four phases: attention, retention, production, and motivation. Through these phases, learner performance can be developed and positively directed to the production of the required behavior [21]. The $\mathrm{DEP}_{\mathrm{s}}$ can allow for the representation of these phases either directly, via presenting modeling through live sessions with teachers or peers, or indirectly, via videos [3]. Accordingly, the present study seeks to investigate the extent to which student intentions to use the $\mathrm{DEP}_{\mathrm{S}}$ are an application of observational learning 
principles, and how this will affect their perceived ease of use and perceived usefulness. Hence, the present study proposes the following questions and hypotheses:

(1) What is the relationship between student observational learning through $\mathrm{DEP}_{\mathrm{s}}$ and their perceived ease of using them?

Hypotheses 1 (H1). The student observational learning through $D E P_{s}$ will positively affect perceived ease of use.

(2) What is the relationship between student observational learning through $\mathrm{DEP}_{\mathrm{s}}$ and their perceived usefulness?

Hypotheses 2 (H2). The student observational learning through DEP $P_{s}$ will positively affect the perceived usefulness.

As Bandura mentioned [24], the fourth stage of observational learning is known as motivation, which consists of all forms of internal and external scaffolding that stand behind the individual's keenness to follow a particular model and to emulate it. Bandura's SCT is concerned with the principle of scaffolding, which helps to generate the positive behaviors that are required for learning when they are presented consistently [21,25-27]. This is especially helpful when the scaffold is provided with the opportunity for the learner to fully control the learning environment $[24,28]$. Hence, the present study proposes the following questions and hypotheses:

(3) What is the relationship between learner control with scaffolding through $\mathrm{DEP}_{s}$ and the students' perceived ease of use?

Hypotheses 3 (H3). Learner control with scaffolding through DEP will positively affect the students' perceived ease of use.

(4) What is the relationship between learner control with scaffolding through $\mathrm{DEP}_{\mathrm{s}}$ and the students' perceived usefulness?

Hypotheses 4 (H4). Learner control with scaffolding through DEP $P_{s}$ will positively affect the students' perceived usefulness.

The concept of self-regulation is one whose theoretical foundations extends back to Bandura's SCT. Self-regulation helps an individual to produce the desired behavior through their interaction with the surrounding environment. As the self-organized individual has clear knowledge of their goals, strengths, and weaknesses, based on these goals, they determine their behavior, move forward with high motivation, and when they succeed in achieving the desired ends or fail to do so, evaluate their performance and organize their behavior toward achieving the next goal $[29,30]$. Individuals with a high level of selfregulation ability have several characteristics, including the ability to plan, self-evaluate, self-monitor, make decisions, and persevere in pursuit of set goals [29,31,32]. While there has been extensive research looking at the benefits of a high level of self-regulation in the traditional learning environment, there is a scarcity of works that care about the role of self-regulation in student intentions to use $\mathrm{DEP}_{\mathrm{s}}$ and its effect on the perceived ease of use and perceived usefulness according to a proposed theoretical model. Hence, the current study proposes the following questions and hypotheses:

(5) What is the relationship between self-regulation through $\mathrm{DEP}_{\mathrm{s}}$ and the students' perceived ease of use?

Hypotheses 5 (H5). Self-regulation through DEP sill positively affect the students' perceived ease of use.

(6) What is the relationship between self-regulation through $\mathrm{DEP}_{\mathrm{s}}$ and the students' perceived usefulness?

Hypotheses 6 (H6). Self-regulation through DEP will positively affect the perceived usefulness of the students. 
The related theoretical framework emphasized that self-efficacy is related to future performance $[33,34]$. Additionally, it has been well established by psychologists that selfefficacy is closely related to the field of ICT, as it serves as an important determinant for measuring student perceptions of using a specific type of technology [33-36]. Furthermore, Hill, Smith, and Mann [37] have illustrated that there is a relationship between the selfefficacy and acceptance of using a computer. Additionally, efficiency must be frequently evaluated by the individuals who are going to use a given technology because it helps to tailor programs according to their individual needs [36,38]. Accordingly, the present study seeks to investigate the effect of computer self-efficacy on the student intentions to use the $\mathrm{DEP}_{\mathrm{S}}$ through their perceived ease of use and perceived usefulness. Hence, the current study proposes the following questions and hypotheses:

(7) What is the relationship between computer self-efficacy through $\mathrm{DEP}_{\mathrm{s}}$ and the students' perceived ease of use?

Hypotheses 7 (H7). Computer self-efficacy through DEP will positively affect the students' perceived ease of use.

(8) What is the relationship between computer self-efficacy through $\mathrm{DEP}_{\mathrm{s}}$ and the students' perceived usefulness?

Hypotheses 8 (H8). Computer self-efficacy through DEP will positively affect the perceived usefulness of students.

Moreover, in the present study, we include the perceived variables of perceived ease of use and perceived usefulness. These are crucial in the TAM model to explore the acceptance of technology [17,39-41]. In our proposed model, we investigate whether both perceived ease of use and perceived usefulness will affect student intentions to use $\mathrm{DEP}_{\mathrm{s}}$. We are also looking into whether perceived ease of use is affected by perceived usefulness through $\mathrm{DEP}_{\mathrm{s}}$. Hence, the present study proposes the following questions and hypotheses:

(9) What is the relationship between perceived ease of use through $\mathrm{DEP}_{\mathrm{S}}$ and perceived usefulness?

Hypotheses 9 (H9). Perceived ease of use through DEP will positively affect perceived usefulness.

(10) What is the relationship between perceived ease of use and the intention to use $\mathrm{DEP}_{\mathrm{s}}$ ?

Hypotheses 10 (H10). Perceived ease of use will positively affect the intention to use DEP.

(11) What is the relationship between perceived usefulness and the intention to use $\mathrm{DEP}_{\mathrm{s}}$ ?

Hypotheses 11 (H11). Perceived usefulness will positively affect the intention to use DEP .

Based on past imperial standpoints, the present study links the principles of the SCTobservational learning, learner control with scaffolding, self-regulation, and computer self-efficacy - to other important constructs in the TAM model that are related to student intentions to use $\mathrm{DEP}_{\mathrm{s}}$, such as perceived ease of use and perceived usefulness. The following model has been developed to measure student intentions to use $\mathrm{DEP}_{\mathrm{s}}$ (see Figure 1). 


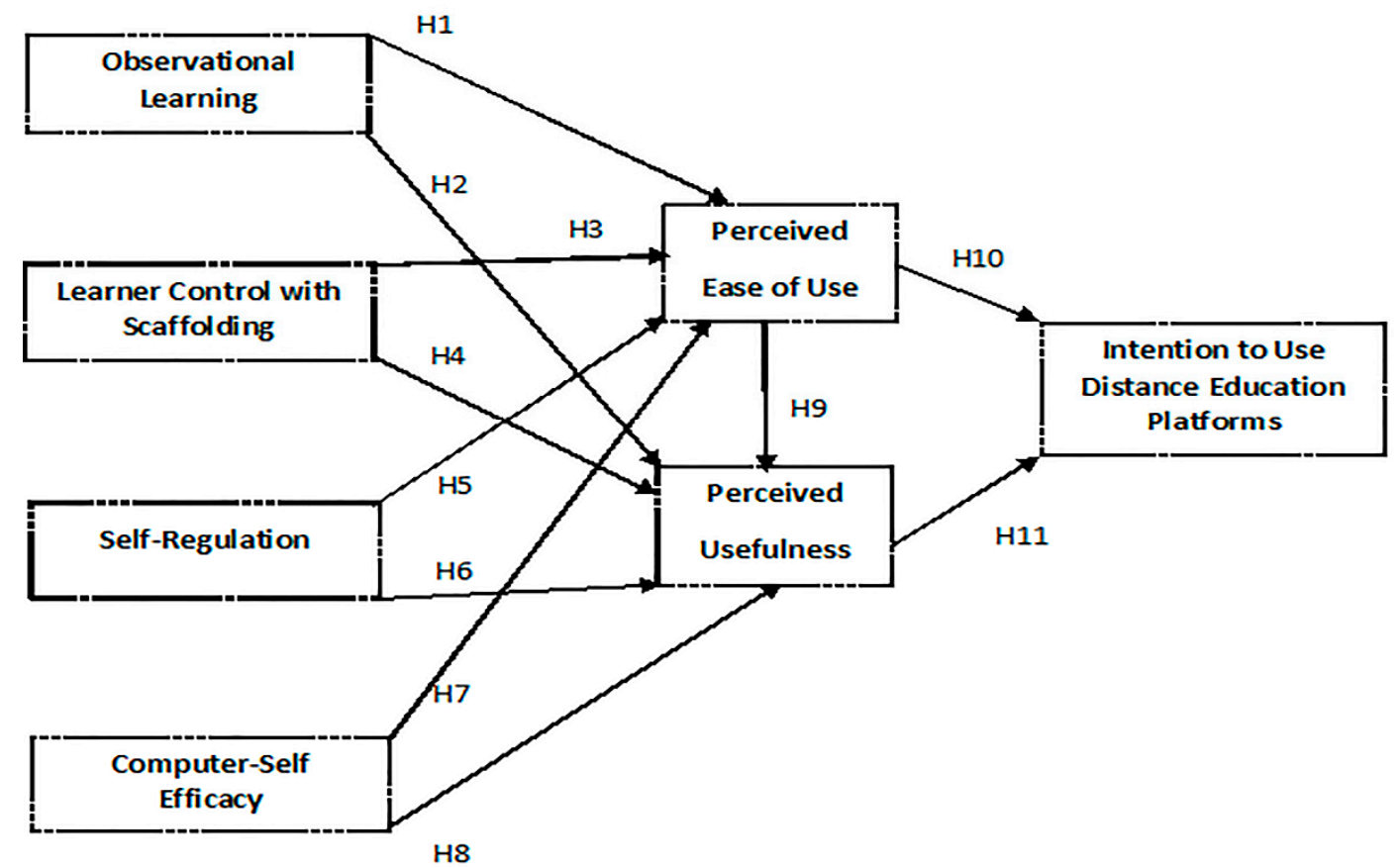

Figure 1. Research model and hypotheses.

The following sections explore the theoretical constructs of the research.

A. Social Cognitive Theory (SCT):

SCT is based on individual learning through either direct experience or observation, in which the learning is happening via selectively observing and remembering the behavior of others in a social framework $[24,30,31,42]$. Thus, there must be an attractive and trustworthy model to ensure that observational learning takes place. This model may be a teacher, a student, or any mediator with specific criteria that can be followed [21-23]. From this standpoint, the present study seeks to investigate the role of SCT in student intentions to use $\mathrm{DEP}_{\mathrm{s}}$ by activating the principles of SCT.

Observational learning: (OL) includes five basic processes: attention, memorization, production, scaffolding, and reinforcement [21-23]. The individual should pay attention to the characteristic features of the model's performance so that they are perceived and stored properly, whether visually, verbally, or both, for ease of remembering in the future $[24,30,31,42]$. The present study did not find any research combining observational learning and student intentions to use distance education platforms. There is a shortage of works that explore the relationship between observational learning and both perceived ease of use and perceived usefulness.

Learner control with scaffolding: (LCS) Vygotsky was the first to put forward the idea of scaffolding and the first to point out the importance of presenting it to learners in a sociocultural context, given that the learning process is the outcome of a set of socio-cultural interactions that occur between learners and teachers or their more mature or experienced peers [43]. The idea of learning scaffolding is based on Vygotsky's social theory, which traces the idea of support systems back to Vygotsky's concept of the zone of proximal development (ZPD) [43]. Scaffolding is defined as a means of guiding and directing students in the e-learning environment and providing them with appropriate assistance to achieve the required educational goals [44]. It consists of a set of aids, directives, and designs that are provided to the learner during the learning process within electronic environments as guidelines to help them accomplish learning tasks and efficiently and effectively achieve the goals required [45]. Several studies have confirmed that different degrees and types of scaffolds should be provided to suit the level and experience of each individual learner. There are also many ways to provide scaffolding depending on the nature of each educational situation and the goal to be achieved through it. Moreover, 
scaffolded learning, if linked to the student's control of the learning environment, can work to expand the field of learning and can transform it from the traditional mechanical image to the constructive process image. Scaffolding also arouses the learner's interest, increases their motivation, and provides them with immediate feedback, thus eliciting the correct response and correcting misunderstanding [46-48]. Based on the this information, we conclude that learner control with scaffolding is presented in a social framework; furthermore, scaffolding is the fourth phase of observational learning. Moreover, there are many studies that have dealt with different types of scaffolding systems within e-learning environments, as mentioned, but the present study did not encounter any theoretical models that investigate the role of learner control with scaffolding in influencing the intentions of students to use $\mathrm{DEP}_{\mathrm{s}}$ through the two variables of PEOU and perceived usefulness.

Self-regulation: (SR) Zimmermann defined self-regulation as an organized cognitive mental process in which the learner is an active participant until their learning goal is achieved [49]. There are three basic components of self-regulation: strategies that include a purpose and means, self-feedback, and recognition of the importance of preparation and action. These components lead to highly efficient learning [32,50]. Purdie presented a model that includes five components of self-organized learning: goal setting and planning; record keeping and observation; and recitation, memorization, and seeking social assistance [51]. Considering these theoretical standpoints, we can conclude that self-regulation takes place in a social learning environment as well and is integrated with Bandura's SCT [30,31,52]. While many studies have dealt with the role of self-regulation in student acceptance of e-learning environments $[53,54]$, there is a scarcity of research investigating the relationship between self-regulation and perceived ease of use, perceived usefulness, and intentions to use DEP .

Computer self-efficacy: (CSE) The concept of self-efficacy constitutes a major focus of SCT, which holds that individuals can control their behavior with their personal beliefs. Additionally, individuals who have a system of self-beliefs are enabled to control their feelings and thoughts, as these beliefs are the key to the driving forces of individual behavior [55]. Emphasizing this context, many studies have linked self-efficacy to computer self-efficacy, as several works have mentioned that the level of computer proficiency can be considered one of the indicators of self-efficacy $[38,56]$. It has also been shown that students' computer self-efficacy is linked to their learning performance in e-learning environments and can positively predict that performance [57-59]. Moreover, it has been illustrated that students' computer self-efficacy is one of the crucial components in elearning environments $[60,61]$. It is thus clear that there is a strong relationship between self-efficacy and computer self-efficacy and that they both have an impact in e-learning environments, especially those that are developed in the light of a social work framework. Therefore, the present study seeks to investigate computer self-efficacy and its impact on the intention of students to use $\mathrm{DEP}_{\mathrm{S}}$ and its role in both PEOU and perceived usefulness.

B. Technology Acceptance Model (TAM):

The TAM model was invented by Davis in 1989, and it is considered to be one of the most widespread and applied models in the field of information systems. It is assumed that the acceptance of information systems by individuals or users is determined by two main variables and perceived usefulness (PU) and that these two variables are affected by several external factors [41]. The TAM model has been extensively tested on many samples of different situations and sizes. In e-learning, studies have dealt with different variables of the TAM model, which have been linked to the intention to use an e-learning system [62-66]. Generally, e-learning systems have diverse content; consequently, many research studies have used TAM to examine the concept of e-learning and its diverse variables, either based on TAM or the expansion and modification of the model. In the present study, we propose a new theoretical model that can predict student intentions to use $\mathrm{DEP}_{\mathrm{s}}$. The model involves external variables that arise from the SCT as well as both the perceived and outcome variables. 
Perceived ease of use and perceived usefulness: In the present study, perceived ease of use (PEU) is defined as the degree to which higher education students believe that their use of $\mathrm{DEP}_{\mathrm{s}}$ requires little effort and is easy and flexible. Perceived usefulness is defined as the degree to which higher education students believe that their use of DEP $\mathrm{s}_{\mathrm{S}}$ would provide them with a benefit in their use, enhance the level of their performance, improve the quality of their education, increase teaching motivation, and facilitate interaction with their teachers and colleagues. $\mathrm{DEP}_{\mathrm{S}}$ help in saving time, giving lectures, and all forms of educational activities that can be provided to a larger number of students. Many studies have proven the essential role that perceived ease of use and perceived usefulness play in the intention to use e-learning systems [67-69].

Intention to use: In the present study, this is understood as the degree to which higher education students intend to use $\mathrm{DEP}_{\mathrm{S}}\left(\mathrm{IUDEP}_{\mathrm{S}}\right)$ for various learning activities. The behavioral intention to use allows us to predict whether students will adopt the technology of $\mathrm{DEP}_{\mathrm{s}}$ within the framework of a social action stemming from the principles of SCT.

\section{Methodology}

This section is divided into three sections to present the details of a sufficient procedure for the current study as below:

\subsection{Sample}

Ethical approval to conduct this study was obtained from the Research Ethics Committee at King Faisal University, under application No. KFU-REC/2021-06-19. Three universities in the Kingdom of Saudi Arabia participated in this study. A total of 453 students were enrolled in undergraduate and postgraduate courses in the second term at the time of the study. As cited in Abdel Hamid [70], "the appropriate sample size should not be less than the number of variables multiplied by 20 " (p. 462). However, this study had seven variables (observational learning, learner control with scaffolding, self-regulation, computer self-efficacy, perceived ease of use, perceived usefulness, and intention to use $\left.\mathrm{DEP}_{\mathrm{s}}\right)$, so the sample size of $453(7 \times 20=140<453)$ was more than suitable. All of the demographic details of the participants are addressed in Table 1. As shown in Figures 2 and 3, the normal distribution for the participants was presented as a condition for developing the next statistical procedures. The students gave their consent for their participation in the study, and they were free to leave the study whenever they wanted.

Table 1. Demographic details of the participants.

\begin{tabular}{|c|c|c|c|c|}
\hline & Item & $\begin{array}{l}\text { Number and } \\
\text { Percentage }\end{array}$ & Mean & $\begin{array}{l}\text { Standard } \\
\text { Deviation }\end{array}$ \\
\hline \multirow{2}{*}{ Gender } & Males & $172(38.0 \%)$ & \multirow{2}{*}{1.620} & \multirow{2}{*}{0.485} \\
\hline & Females & $281(62.0 \%)$ & & \\
\hline \multirow{4}{*}{ Age } & Less than 20 & $31(6.8 \%)$ & \multirow{4}{*}{2.123} & \multirow{4}{*}{0.593} \\
\hline & $21-25$ & $359(79.2 \%)$ & & \\
\hline & $26-30$ & $39(8.6 \%)$ & & \\
\hline & More than 30 & $24(5.3 \%)$ & & \\
\hline \multirow{5}{*}{ Faculty } & Education & $297(65.6 \%)$ & \multirow{5}{*}{1.949} & \multirow{5}{*}{1.575} \\
\hline & Society & $80(17.7 \%)$ & & \\
\hline & Agriculture & $32(7.1 \%)$ & & \\
\hline & Arts & $42(9.3 \%)$ & & \\
\hline & Finance & $2(.4 \%)$ & & \\
\hline
\end{tabular}


Table 1. Cont.

\begin{tabular}{|c|c|c|c|c|}
\hline & Item & $\begin{array}{l}\text { Number and } \\
\text { Percentage }\end{array}$ & Mean & $\begin{array}{c}\text { Standard } \\
\text { Deviation }\end{array}$ \\
\hline \multirow{2}{*}{ Academic major } & Scientific major & $174(38.4 \%)$ & \multirow{2}{*}{1.615} & \multirow{2}{*}{0.486} \\
\hline & Literary major & $279(61.6 \%)$ & & \\
\hline \multirow{2}{*}{ Stage } & Undergraduate level & $363(80.1 \%)$ & \multirow{2}{*}{1.207} & \multirow{2}{*}{0.437} \\
\hline & Postgraduate level & $88(19.4 \%)$ & & \\
\hline \multirow{4}{*}{$\begin{array}{c}\text { kind of platforms } \\
\text { used }\end{array}$} & Microsoft Teams & $41(9.1 \%)$ & \multirow{4}{*}{3.406} & \multirow{4}{*}{1.00} \\
\hline & Zoom & $50(11.0 \%)$ & & \\
\hline & Microsoft Teams and Zoom & $46(10.2 \%)$ & & \\
\hline & $\begin{array}{c}\text { Different kinds of platforms, } \\
\text { such as Classera, Google Meet, } \\
\text { and Duo }\end{array}$ & $316(69.8 \%)$ & & \\
\hline
\end{tabular}

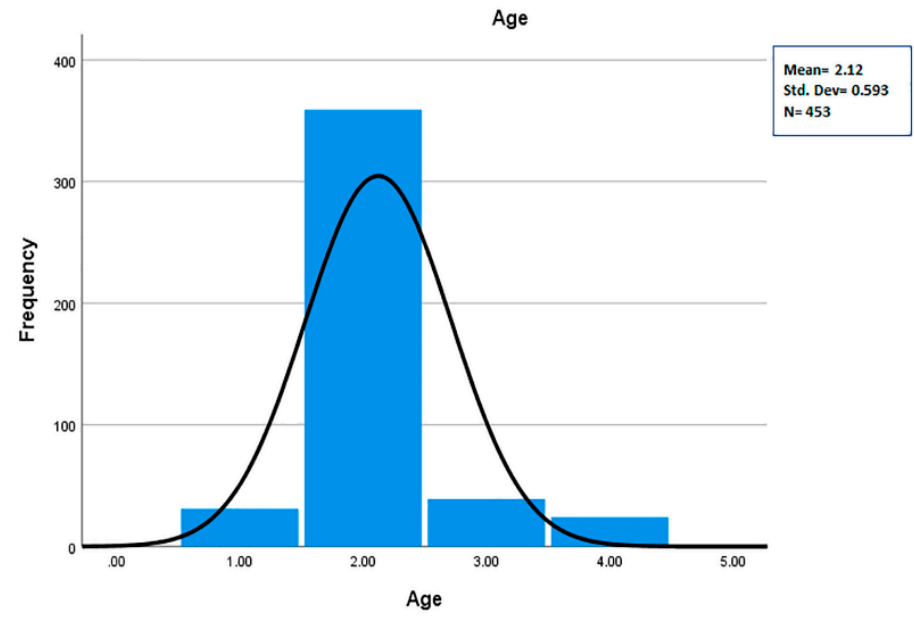

Figure 2. Normal distribution for the sample in terms of gender.

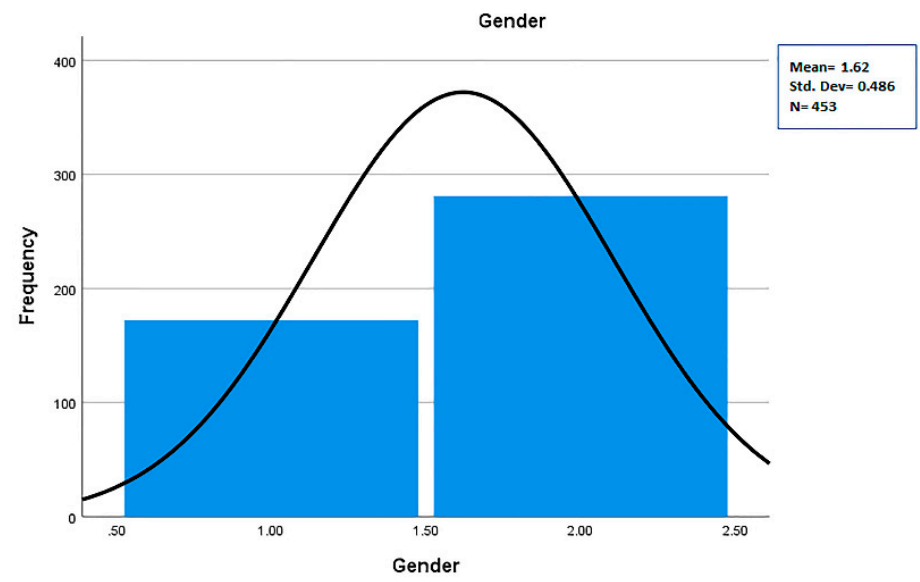

Figure 3. Normal distribution for the sample in terms of age.

\subsection{Instrument}

By drawing on the SCT and TAM models, a questionnaire was developed to assess student intentions to use $\mathrm{DEP}_{\mathrm{s}}$. The questionnaire comprised 30 items that were distributed across seven constructs: observational learning (seven items), learner control with scaffolding (four items), self-regulation (four items), computer self-efficacy (five items), perceived ease of use (four items), perceived usefulness (four items), and intention to use $\mathrm{DEP}_{\mathrm{s}}$ (two items). To calculate the interrater and content validity, the questionnaire was presented 
to three experts in the instructional technology field. The experts indicated that the questionnaire was highly suitable and relevant to the objectives and levels and that the items were precise, scientifically accurate, and relevant to the constructs and to the procedure that the students would undergo. A five-point Likert scale was adopted to estimate the students' scores on the questionnaire (strongly disagree $=1$; disagree $=2$; neutral $=3$; agree $=4$; strongly agree $=5$ ). The scores for the questionnaire ranged from 30 (lowest) to 150 (highest). See Appendix A (Table A1) for more details.

\subsection{Pilot Study}

To calculate both the statical validity and reliability, 150 students participated in the pilot study. SPSS (v. 26) was used to measure the validity and reliability of the instrument. The Table 2 displays the overall Cronbach's alpha values for the questionnaire on the students' intentions to use $\mathrm{DEP}_{\mathrm{S}}$ (30 statements), and from it, it becomes clear that the total alpha coefficient of the questionnaire was equal to 0.928 , which is indicative of high reliability. The first column also displays Cronbach's alpha coefficient (with the number of questionnaire statements), and each time the scores for one of the phrases was omitted from the total score of the questionnaire, and from it, it becomes clear that all of the statements are fixed or contribute to increasing the overall stability of the questionnaire. It was also found that the total alpha coefficient of the questionnaire, when omitting each statement separately, was less than or equal to the total alpha coefficient of the questionnaire without deleting any statement, as the alpha coefficients extended when deleting the expressions from 0.919 to 0.927 , and all of them were less than or equal to the total alpha coefficient of the questionnaire without deleting any statement, equaling 0.928 . That is, the inclusion of all the expressions from the questionnaire does not lead to a decrease in the overall stability factor of the questionnaire, and the exclusion of the expressions leads to a reduction in the total alpha coefficient of the questionnaire, indicating the stability of all of the questionnaire statements. The second column displays the corrected item-total correlation coefficient of the statement with the total score of the questionnaire when omitting the degree of the statement from the total score of the questionnaire, and this parameter indicates the validity of the questionnaire's statements by considering the rest of the questionnaire as a quote for the phrase. It is clear from this table that the correlation coefficients extend from 0.168 to 0.693 and that all of them are statistically significant at the level of 0.1 , which indicates the validity of all the questionnaire statements. The third column shows that the overall Cronbach's alpha of the seven research variables, including observational learning (0.774), learner control with scaffolding (0.794), self-regulation (0.665), computer self-efficacy (761), perceived ease of use (0.801), perceived usefulness (0.914), and intention to use $\mathrm{DEP}_{\mathrm{s}}$ (0.826), were high, acceptable, and significant $(\alpha=0.01)$, which indicated the validity of the instrument.

Table 2. Reliability and validity coefficients of the study's instrument $(N=150)$.

\begin{tabular}{|c|c|c|c|}
\hline Item & $\begin{array}{c}\text { Cronbach's Alpha If Item } \\
\text { Deleted }\end{array}$ & $\begin{array}{l}\text { Corrected Item-Total } \\
\text { Correlation }\end{array}$ & $\begin{array}{c}\text { Cronbach's Alpha of } \\
\text { Variable }\end{array}$ \\
\hline Observational learning 1 & 0.923 & 0.362 & \multirow{7}{*}{$0.774^{* *}$} \\
\hline Observational learning 2 & 0.921 & 0.516 & \\
\hline Observational learning 3 & 0.922 & 0.454 & \\
\hline Observational learning 4 & 0.921 & 0.550 & \\
\hline Observational learning 5 & 0.926 & 0.196 & \\
\hline Observational learning 6 & 0.919 & 0.623 & \\
\hline Observational learning 7 & 0.919 & 0.673 & \\
\hline
\end{tabular}


Table 2. Cont.

\begin{tabular}{|c|c|c|c|}
\hline Item & $\begin{array}{c}\text { Cronbach's Alpha If Item } \\
\text { Deleted }\end{array}$ & $\begin{array}{l}\text { Corrected Item-Total } \\
\text { Correlation }\end{array}$ & $\begin{array}{c}\text { Cronbach's Alpha of } \\
\text { Variable }\end{array}$ \\
\hline Learner control with scaffolding 1 & 0.921 & 0.546 & \multirow{4}{*}{0.794} \\
\hline Learner control with scaffolding 2 & 0.921 & 0.478 & \\
\hline Learner control with scaffolding 3 & 0.921 & 0.472 & \\
\hline Learner control with scaffolding 4 & 0.921 & 0.556 & \\
\hline Self-regulation 1 & 0.920 & 0.567 & \multirow{4}{*}{0.665} \\
\hline Self-regulation 2 & 0.921 & 0.506 & \\
\hline Self-regulation 3 & 0.927 & 0.168 & \\
\hline Self-regulation 4 & 0.923 & 0.354 & \\
\hline Computer self-efficacy 1 & 0.921 & 0.530 & \multirow{5}{*}{0.761} \\
\hline Computer self-efficacy 2 & 0.921 & 0.538 & \\
\hline Computer self-efficacy 3 & 0.921 & 0.539 & \\
\hline Computer self-efficacy 4 & 0.921 & 0.545 & \\
\hline Computer self-efficacy1 5 & 0.920 & 0.546 & \\
\hline Perceived ease of use 1 & 0.920 & 0.604 & \multirow{4}{*}{0.801} \\
\hline Perceived ease of use 2 & 0.923 & 0.431 & \\
\hline Perceived ease of use 3 & 0.921 & 0.491 & \\
\hline Perceived ease of use 4 & 0.920 & 0.608 & \\
\hline Perceived usefulness 1 & 0.919 & 0.622 & \multirow{4}{*}{0.914} \\
\hline Perceived usefulness 2 & 0.919 & 0.677 & \\
\hline Perceived usefulness 3 & 0.919 & 0.651 & \\
\hline Perceived usefulness 4 & 0.918 & 0.693 & \\
\hline Intention to use $\mathrm{DEP}_{\mathrm{s}} 1$ & 0.919 & 0.648 & \multirow{2}{*}{0.826} \\
\hline Intention to use $\mathrm{DEP}_{\mathrm{s}} 2$ & 0.920 & 0.599 & \\
\hline
\end{tabular}

** Sig. at $(\alpha=0.01)$.

\section{Data Analysis and Results}

This section explores both the data analysis and results as below:

\subsection{Model Analysis Data}

A structural equation model (SEM) and third-order confirmatory factor analysis (CFA), alongside calculations of the convergent and discriminant validity, were applied. A structural model was also presented. In Figure 4, the measurement model displays the items and latent variables for student intentions to use $\mathrm{DEP}_{\mathrm{s}}$ through the SCT with the TAM model. There are some tools that can be adopted as indices to assess the model estimation. According to Hu and Bentler [71], Byrne [72], and Kline [73], the normed chi-square, chisquare/degree of freedom, root-mean-square residual (RMR), goodness-of-fit index (GFI), adjusted GFI (AGFI), normed fit index (NFI), relative fit index (RFI), incremental fit index (IFI), Tucker-Lewis coefficient (TLI), comparative fit index (CFI), and the root-mean-square error of approximation (RMSEA) are the tools that can be used to estimate the model. Several modifications had to be made to meet these requirements. Accordingly, five items were deleted from the questionnaire: observational learning 6, computer self-efficacy 3 , computer self-efficacy 5 , and perceived usefulness 4 . Considering the modification indices, these items had weak correlation coefficients between them and the rest of the items, and their degrees of error were high, so they were deleted to improve the model fit. Therefore, 
the final number of items was 26 instead of 30 . Table 3 displays the goodness-of-fit indices.

It is clear that the measurement model has an acceptable goodness of fit.

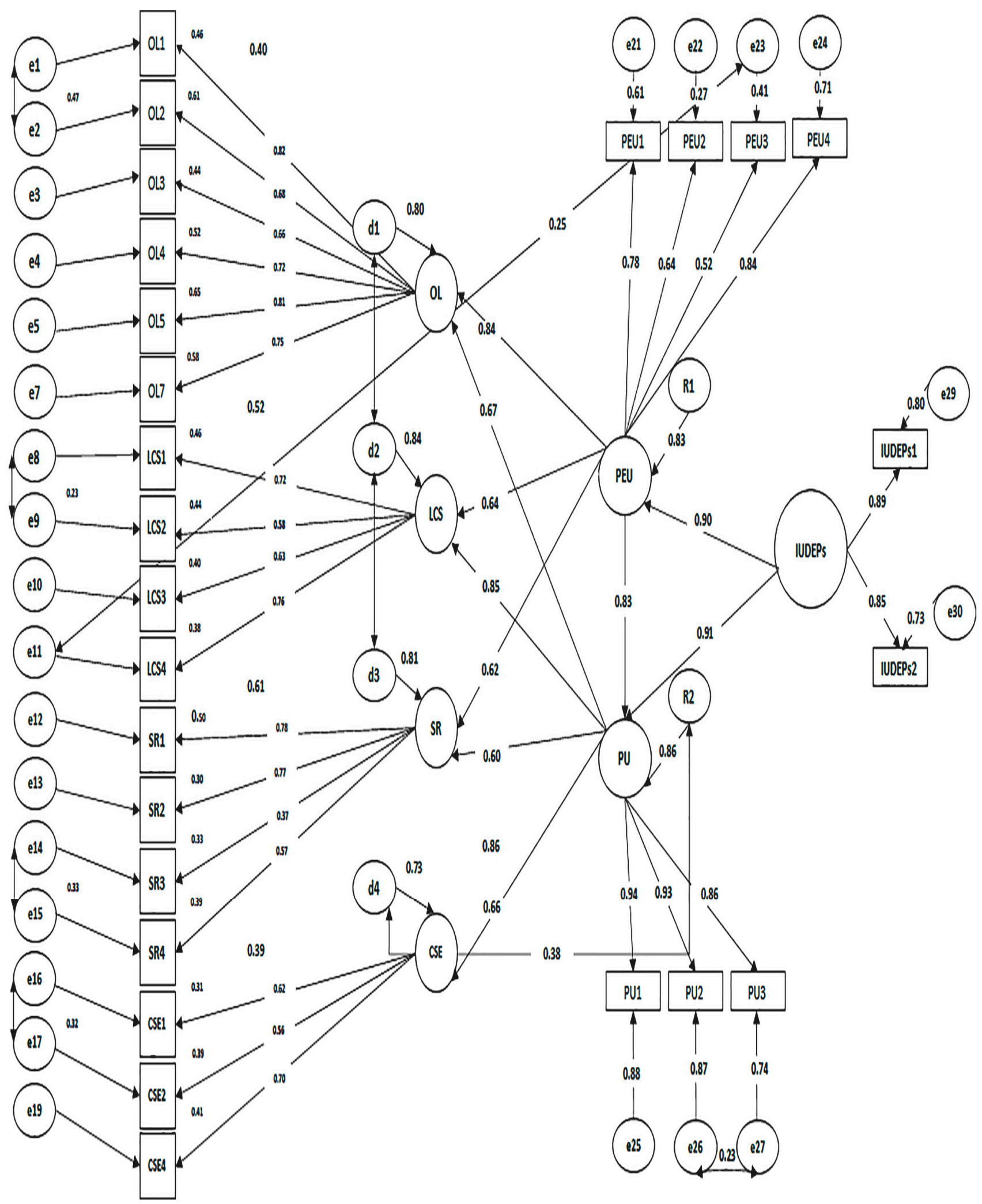

Figure 4. Measurement model for intention to use $\mathrm{DEP}_{\mathrm{s}}$. 
Table 3. Summary of goodness fit indices for the measurement model (SCT and TAM; $N=453$ ).

\begin{tabular}{ccc}
\hline Type of Measure & Recommended Value & Measurement Model Value \\
\hline Chi-square $(\chi 2)$ & $\leq 3.5-0$ (perfect fit) and $(\varrho>0.01)$ & $668.712 / 266$ \\
\hline Normed chi-square $(\chi 2)$ & Value should be $>1.0$ and $<5.0$ & 2.514 \\
\hline (RMR) & Value should be $<0.05$ & 0.043 \\
\hline GFI & Value should be $\geq 0.90$ & 0.901 \\
\hline AGFI & Value should be $\geq 0.90$ & 0.960 \\
\hline Normed fit index (NFI) & Value should be $\geq 0.90$ & 0.908 \\
\hline Relative fit index (RFI) & 0.977 \\
\hline Incremental fit index (IFI) & Value should be $\geq 0.90$ & 0.942 \\
\hline Tucker-Lewis index (TLI) & Value should be $\geq 0.90$ & 0.929 \\
\hline Comparative fit index (CFI) & Value should be $\geq 0.90$ & 0.942 \\
\hline $\begin{array}{c}\text { Root-mean-square error of } \\
\text { approximation (RMSEA) }\end{array}$ & Value should be $\geq 0.90$ & 0.058
\end{tabular}

\subsection{Measurement Model}

Convergent and discriminant validity is the most essential analysis to calculate the validity of a measurement model. Before calculating the validity, some indicators must be achieved. Byrne [72] and Hair et al. [74] have emphasized that the measurement model must match the data. Moreover, the indices of the goodness of fit for the model must be in the accepted range. However, most biometric loading values should be equal to or more than 0.07. For the current model, all of these indicators were achieved. Accordingly, both the composite reliability (CR), average variance extracted (AVE), and the square roots of AVE (discriminant validity-DV) were calculated. Table 4 displays the values for the CR, which ranged between 1.469 and 4.383. Alongside this, AVE ranged from 0.500 to 0.830 . Moreover, the DV ranged between 0.618 and 0.911 . All of the values matched with the recommendations stated in Fornell and Larcker [75].

Table 4. Composite reliability, convergent validity, and discriminant validity for the measurement model (SCT and TAM).

\begin{tabular}{cccc}
\hline Latent Variables & CR $>\mathbf{0 . 7}$ & AVE $\geq \mathbf{0 . 0 5}<$ CR & (DV) $>$ Correlation \\
\hline Observational learning & 4.383 & 0.536 & 0.660 \\
\hline Learner control with scaffolding & 3.169 & 0.557 & 0.676 \\
\hline Self-regulation & 3.467 & 0.583 & 0.618 \\
\hline Computer self-efficacy & 2.814 & 0.595 & 0.628 \\
\hline Perceived ease of use & 2.998 & 0.500 & 0.707 \\
\hline Perceived usefulness & 1.508 & 0.830 & 0.911 \\
\hline Intention to use DEP & 1.469 & 0.765 & 0.874 \\
\hline
\end{tabular}

\subsection{Structure Model Analysis}

Path modeling analysis was adapted to investigate the student intentions to use DEP via the TAM model through SCT. CFA was carried out using structural equation modeling (SEM). Figure 5 shows that six hypotheses were accepted and that another five were rejected. Table 5 displays the main statistics for the model and its hypotheses; specifically, it displays the values for the unstandardized coefficients $(\beta)$ and the standard errors (SE) for the structural model. The basic statistical indicators of the model are good. 


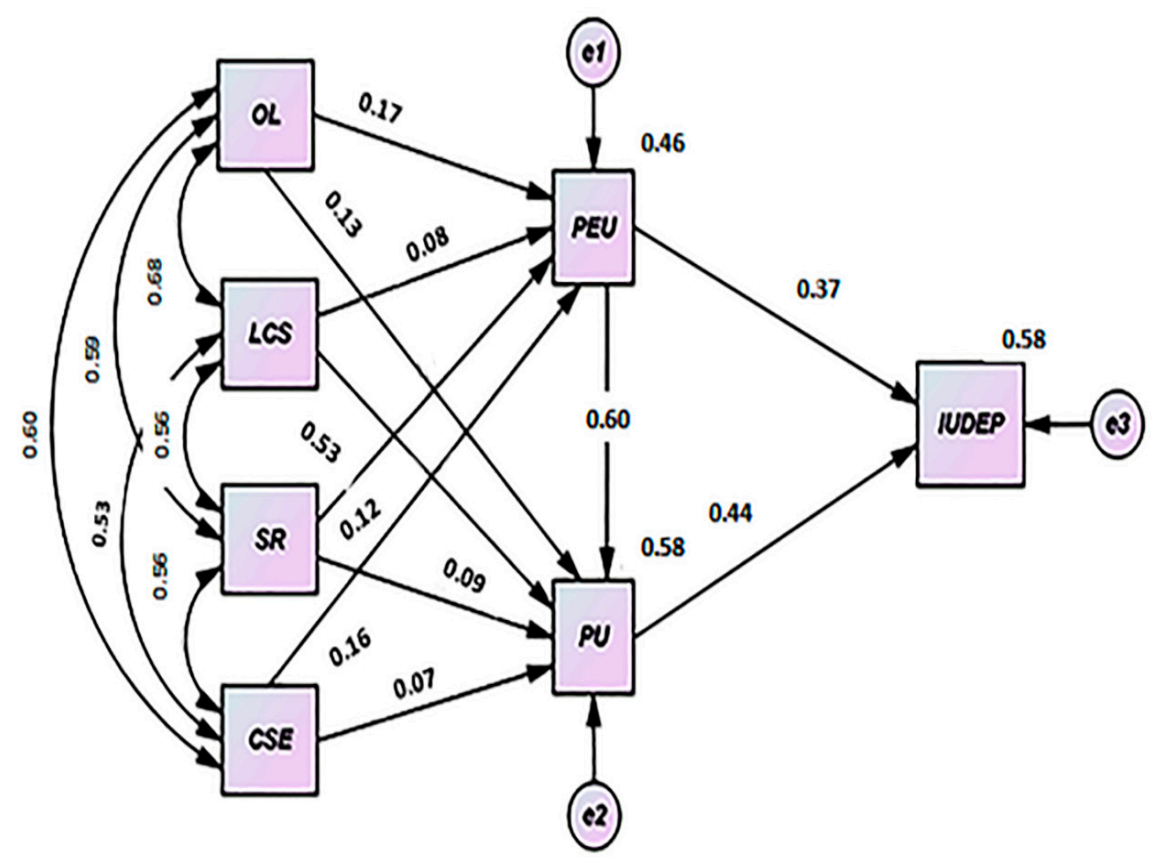

Figure 5. Results for the proposed model for intention to use $\mathrm{DEP}_{\mathrm{s}}$.

Table 5. Hypothesis testing results of the structural model.

\begin{tabular}{|c|c|c|c|c|c|c|c|}
\hline $\mathbf{H}$ & Independent & Dependent & Estimate & S.E. & C.R. & $p$ & Results \\
\hline $\mathrm{H} 1$ & Observational learning & Perceived ease of use & 0.141 & 0.043 & 3.252 & 0.000 & Supported \\
\hline $\mathrm{H} 2$ & Observational learning & Perceived usefulness & 0.109 & 0.043 & 2.558 & 0.011 & Unsupported \\
\hline H3 & $\begin{array}{l}\text { Learner control with } \\
\text { scaffolding }\end{array}$ & Perceived ease of use & -0.104 & 0.063 & -1.652 & 0.098 & Unsupported \\
\hline $\mathrm{H} 4$ & $\begin{array}{l}\text { Learner control with } \\
\text { scaffolding }\end{array}$ & Perceived usefulness & 0.227 & 0.062 & 3.681 & 0.000 & Supported \\
\hline $\mathrm{H} 5$ & Self-regulation & Perceived ease of use & 0.133 & 0.055 & 2.440 & 0.015 & Unsupported \\
\hline H6 & Self-regulation & Perceived usefulness & -0.113 & 0.054 & -2.105 & 0.035 & Unsupported \\
\hline $\mathrm{H} 7$ & Computer self-efficacy & Perceived ease of use & 0.510 & 0.045 & 11.405 & 0.000 & Supported \\
\hline H8 & Computer self-efficacy & Perceived usefulness & 0.076 & 0.050 & 1.526 & 0.127 & Unsupported \\
\hline H9 & Perceived ease of use & Perceived usefulness & 0.670 & 0.046 & 14.585 & 0.000 & Supported \\
\hline H10 & Perceived ease of use & $\begin{array}{l}\text { Intention to use } \\
\mathrm{DEP}_{\mathrm{s}}\end{array}$ & 0.183 & 0.022 & 8.336 & 0.000 & Supported \\
\hline H11 & Perceived usefulness & $\begin{array}{l}\text { Intention to use } \\
\mathrm{DEP}_{\mathrm{S}}\end{array}$ & 0.195 & 0.020 & 9.871 & 0.000 & Supported \\
\hline
\end{tabular}

\subsubsection{Social Cognitive Theory (SCT)}

According to Figure 5 and Table 5 , the relationship between observational learning and perceived ease of use was significant $(\beta=0.141, t=3.252, p<0.001)$. This means that there was a significant and positive relationship between observational learning and perceived ease of use. Moreover, the structural model shows that observational learning, which is based on SCT, had a positive influence on the students while using $\mathrm{DEP}_{\mathrm{s}}$. Accordingly, the first hypothesis (H1) was accepted. In contrast, it was indicated that there was a negative relationship between observational learning and perceived usefulness $(\beta=0.109, \mathrm{t}=2.558$, $p<0.001$ ). Moreover, the structural model shows that observational learning had a negative influence on the perceived usefulness of using the $\mathrm{DEP}_{\mathrm{s}}$ for students. Accordingly, the second hypothesis (H2) was rejected. It was indicated that there was a negative relationship 
between learner control with scaffolding, and perceived ease of use had an unsignificant effect $(\beta=-0.104, t=-1.652, p<0.001)$. Further, learner control with scaffolding had a bad influence on the perceived ease of use for the $\mathrm{DEP}_{\mathrm{s}}$ for students. As a result, the third hypothesis (H3) was rejected.

In contrast, it was indicated that there was a positive and significant relationship between learner control with scaffolding and perceived usefulness $(\beta=0.227, t=3.681$, $p<0.001)$. Moreover, learner control with scaffolding had a good influence on the perceived usefulness of using the $\mathrm{DEP}_{\mathrm{s}}$ for students. Thus, the fourth hypothesis (H4) was accepted. It was also indicated that there was a negative relationship between self-regulation and perceived ease of use, which was insignificant $(\beta=0.133, t=2.440, p<0.001)$. Self-regulation skills had a bad influence on the ease of use the $\mathrm{DEP}_{\mathrm{s}}$ for students. Accordingly, the fifth hypothesis (H5) was rejected. In addition to the previous results, it was indicated that there was a negative relationship between self-regulation and perceived usefulness and that this was an insignificant relationship ( $\beta=-0.113, \mathrm{t}=-2.105, p<0.001$ ). Self-regulation skills also had a bad influence on the usefulness of using the $\mathrm{DEP}_{s}$ for students, so the sixth hypothesis (H6) was rejected. There was a positive and significant relationship between computer self-efficacy and perceived ease of use $(\beta=0.510, t=11.405, p<0.001)$. Computer self-efficacy had a good influence on the ease of using the $\mathrm{DEP}_{\mathrm{s}}$ for students. Thus, the seventh hypothesis (H7) was accepted. In contrast, it was indicated that there was a negative and insignificant relationship between computer self-efficacy and perceived usefulness ( $\beta=0.076, t=1.526, p<0.001)$. Finally, computer self-efficacy had a bad influence on the usefulness of using the $\mathrm{DEP}_{\mathrm{s}}$ for students. Accordingly, the eighth hypothesis (H8) was rejected.

\subsubsection{Technology Acceptance Model (TAM)}

According to Figure 5 and Table 5, the relationship between perceived ease of use and perceived usefulness was significant $(\beta=0.670, \mathrm{t}=14.585, p<0.001)$. This means that there was a significant and positive relationship between perceived ease of use and perceived usefulness. Moreover, the structural model shows that the perceived ease of use, which is based on the TAM, had a good influence on the usefulness of using the $\mathrm{DEP}_{\mathrm{s}}$ for students. Accordingly, the ninth hypothesis (H9) was accepted. Alongside the previous results, the relationship between perceived ease of use and intention to use $\mathrm{DEP}_{\mathrm{s}}$ was significant $(\beta=0.183, t=8.336, p<0.001)$. Further, perceived ease of use had a good influence on the student intentions to use $\mathrm{DEP}_{\mathrm{s}}$. Accordingly, the tenth hypothesis (H10) was accepted. There was also a significant relationship between perceived usefulness and the intention to use $\operatorname{DEP}_{\mathrm{s}}(\beta=0.195, \mathrm{t}=11.405, p<0.001)$. This means that there was a significant and positive relationship between perceived usefulness and intention to use $\mathrm{DEP}_{\mathrm{s}}$. Finally, the structural model shows that perceived usefulness had a good influence on student intentions to use $\mathrm{DEP}_{\mathrm{s}}$. As a result, the eleventh hypothesis (H11) was accepted.

\section{Discussion and Implications}

The present study aimed to expand the TAM model via external variables through the SCT (observational learning, learner control with scaffolding, self-regulation, and computer self-efficacy). To determine whether the students would adopt the $\mathrm{DEP}_{\mathrm{s}}$ in their future learning process, the study also demonstrated both the proposed model and the hypotheses. Accordingly, six hypotheses were supported, and five hypotheses were rejected. 
It was found that perceived ease of use had a positive impact on perceived usefulness, and this finding is consistent with those reported in a number of studies $[9,17,76-80]$. Moreover, it has been demonstrated by Davis [41] and Mathieson [81] that the TAM confirmed that both perceived ease of use and perceived usefulness are essential factors that determine whether to adopt or use a new e-learning system. In light of this, both factors had a positive and significant effect on the students' intentions to use $\mathrm{DEP}_{\mathrm{s}}$. The following section discusses the four external factors relevant to SCT influencing students ${ }^{\prime}$ perceived ease of use and perceived usefulness and thus their effects on student intentions to use $\mathrm{DEP}_{\mathrm{s}}$. These factors are observational learning, learner control with scaffolding, computer self-efficacy, and self-regulation.

It was found that observational learning had a positive impact on perceived ease of use, which, in turn, positively affected student intentions to use $\mathrm{DEP}_{\mathrm{s}}$. Observational learning, which is an important factor of SCT, consists of many sequential processes, including displaying the ideal learning model, regenerating and refining experience, reinforcing learning, and self-motivation $[21,24,30,31]$. This can be explained by the fact that the $\mathrm{DEP}_{\mathrm{s}}$, which are based on the observational learning approach, are causing students to become familiar with these platforms, which will eventually result in increasing their ease of use. This explanation agrees with those offered by a number of studies $[82,83]$ that have demonstrated that distance education contributes greatly to refining the experience of university students through its ability to provide education flexibly and effectively. Such features make distance education easy to use widely. Therefore, the positive relationship between observational learning and perceived ease of use was confirmed by this study result. Therefore, observational learning was indirectly a positive indicator of student intentions to use $\mathrm{DEP}_{\mathrm{s}}$. However, perceived usefulness was found to be negatively affected by observational learning. Additionally, this result conflicts with Bandura et al. [84], who pointed out that individuals may have bad learning experiences, but through observational learning, they can engage in new learning situations that improve their behavior and create new positive experiences. These new experiences reduce anxiety and engage them in better positive learning settings. This result can be explained as the observational learning processes causing cognitive load, which might negatively affect student perceptions towards $\mathrm{DEP}_{\mathrm{s}}$.

In terms of computer self-efficacy, there was a positive impact of it on perceived ease of use, which, in turn, had a positive impact on student intentions to use $\mathrm{DEP}_{\mathrm{s}}$. This result was in line with those reported by several related studies $[83,85,86]$. These studies demonstrated that the more students possessed good experiences and acceptable computer skills, the more that this would reflect on their perceived ease of using $\mathrm{DEP}_{\mathrm{s}}$ and therefore their intentions to use $\mathrm{DEP}_{\mathrm{s}}$. Moreover, the importance of computer self-efficacy was emphasized by [15] in determining student intentions to use distance education via the perceived ease of use and that universities should take care to implement continuous training to develop computer self-efficacy for their students. Accordingly, the present study showed that computer self-efficacy was highly related to perceived ease of use. However, computer self-efficacy had a negative impact on perceived usefulness. This finding is consistent with the work of [15], who demonstrated that computer self-efficacy had no effect on its perceived usefulness by students. The findings of [87] may offer a better explanation of the current results, as they mentioned that perceptions of self-efficacy can be sufficient to affect an individual's adoption decisions regarding technology use. This means that computer self-efficacy had an indirect negative effect on student intentions to use $\mathrm{DEP}_{\mathrm{s}}$ through perceived usefulness.

Generally, observational learning and computer self-efficacy may be essential factors in the interaction with distance education environments [24,28], but other vital factors also support their effectiveness. Readiness for online learning, enjoyment, motivation, and attitude are all critical factors for success in the distance education platform [88-93]. Accordingly, the students in the present study had a negative perception toward the perceived usefulness of the $\mathrm{DEP}_{\mathrm{s}}$ because they were needed to such factors alongside making both observational learning and computer self-efficacy available. 
Learner control with scaffolding was found to have a negatively affected perceived ease of use. This result may be explained by the finding of [2] (p. 217), who showed that "the distance education course should support students with great flexibility in interacting with their instructor, classmates, and the course content". Moreover, [94] have clarified that distance education should involve a useful and flexible way of learning, which, in turn, leads to higher levels of engagement in the learning setting. Considering these contexts, the students in the present study may have had no sufficient level of control and scaffolding when using $\mathrm{DEP}_{\mathrm{s}}$. That is, learning control with scaffolding had an indirect and negative impact on student intentions to use $\mathrm{DEP}_{\mathrm{s}}$. On the other hand, perceived usefulness was found to be positively affected by learner control with scaffolding. This finding was supported by [48], who demonstrated that scaffolding is effective in the learning process, especially in distance and online learning environments. Learner control with scaffolding provides learners with the experience of knowledge construction, makes the instructional tasks relevant, introduces learning as a social experience, and allows for providing learning in multiple modes [95-99]. In sum, learner control with scaffolding had an indirect and positive impact on student intentions to use $\mathrm{DEP}_{\mathrm{s}}$.

A self-regulation factor showed a negative impact on both perceived ease of use and perceived usefulness. This means that self-regulation factor indirectly and negatively affects student intentions to use $\mathrm{DEP}_{\mathrm{s}}$. These results disagree with the work of Meng and Wang [100], where they demonstrated that self-regulation had a positive and direct relationship with behavioral intention and actual use. The self-regulation process is a critical factor that can contribute to raising individual's intention to use any information system. A possible explanation for such result is that the students in this study may have considered that the self-regulation process in the $\mathrm{DEP}_{\mathrm{S}}$ was not easy to practice or that it required more effort. That is, this difficulty will negatively affect their performance in their future learning and their perceived ease of use as well as their perceived usefulness of $\mathrm{DEP}_{\mathrm{s}}$.

The present study showed that the intention to use $\mathrm{DEP}_{\mathrm{s}}$ has become a crucial factor that can help students to accelerate and improve their learning in higher education, whether at the undergraduate or postgraduate level. Several implications are discussed according to the findings of current study. Higher education institutions have raised a great challenge for their students. It is no longer sufficient to provide appropriate technological innovations in education based on the nature of the courses and the skills they require. Rather, it has become a requirement to provide the perceived of ease of use and usefulness. Usefulness is not sufficient for the e-learning system to be successful, as it should also be easy to use. In this way, students will be able to realize the potential benefits of using such digital platforms in higher education. Moreover, the present results provide several implications for instructional designers, educational software developers, and educational practitioners as they develop their next innovative applications in $\mathrm{DEP}_{\mathrm{s}}$. The construction of these platforms depends on a consideration of the factors of ease of use and perceived usefulness, along with an incorporation of the principles of observational learning, the learner's control of the educational platform with the provision of the necessary scaffolding, and the development of aspects of computer self-efficacy for students to facilitate dealing with these platforms from a technical point of view.

The current study also has some limitations. First, the data were only collected from three universities in the KSA and from students who were enrolled in the undergraduate and postgraduate levels. Thus, this must be considered when generalizing the findings. Furthermore, we did not perform a qualitative analysis of the data, such as by examining the gender of participants, their academic level, or their geographic region. Instead, our focus was limited to conducting a descriptive analysis of the data, so future qualitative studies are highly recommended.

There is tangible importance to this study, as it investigated the principles of SCT that affect student intentions to use $\mathrm{DEP}_{\mathrm{s}}$. It was found that perceived ease of use was positively affected by observational learning and computer self-efficacy, and perceived usefulness 
was positively affected by learner control with scaffolding. Nevertheless, the present study also showed that perceived ease of use is negatively affected by learner control with scaffolding, and perceived usefulness is negatively affected by observational learning and computer self-efficacy. Moreover, both perceived ease of use and perceived usefulness are negatively affected by self-regulation. This requires the consideration of some other critical factors, which are related to one of the crucial principles of the SCT, which is course design. These factors include readiness for online learning, enjoyment, motivation, attitude, flexibility, and reducing the learning effort required in self-regulation settings. Such changes would have a positive effect on perceived ease of use and perceived usefulness while also improving students' intentions to use the $\mathrm{DEP}_{\mathrm{s}}$. Accordingly, more studies strongly recommended that such factors be considered along with the SCT principles.

\section{Conclusions and Future Work}

In conclusion, the results of the present study have shown that observational learning, learner control with scaffolding, and computer self-efficacy are crucial factors of SCT and that such factors can positively influence student intentions to use $\mathrm{DEP}_{\mathrm{s}}$ when employed with the TAM model. Moreover, considering that course instruction and design may be performed in light of these factors, this process will positively influence the perceived ease of use and the perceived usefulness for the adopted e-learning system. However, instructional designers should also consider other factors that may enhance student intentions to use $\mathrm{DEP}_{\mathrm{s}}$, which, in turn, need more investigation to determine the extent to which they effectively contribute to the development of the perceived ease of use and perceived usefulness, which are the initial keys that affect student intentions to use DEP. Perhaps combining scaffolding based on gamification with course design would be a good example of applying SCT with the TAM model. This, in turn, would make both perceived enjoyment and perceived motivation greatly available in the learning setting. The results showed their importance in developing student behavioral intentions toward distance learning platforms. Nevertheless, this model requires more investigation. Follow-up studies are also needed to explore the self-regulation roles played in perceived ease of use and perceived usefulness that positively influence the intention to use $\mathrm{DEP}_{\mathrm{s}}$.

Author Contributions: Conceptualization, A.A.-D., A.D., I.A. and A.A.-A.; methodology, A.A.-D. and I.A.; validation, A.D. and I.A.; formal analysis A.A.-D.; investigation, A.A.-A.; resources, A.D.; data curation, I.A.; writing-original draft preparation, A.A.-D. and A.A.-A.; writing-review and editing, A.A.-D., A.D., I.A. and A.A.-A.; visualization, A.A.-D. and A.D.; supervision, A.A.-D.; project administration, A.A.-D. All authors have read and agreed to the published version of the manuscript.

Funding: This research received no external funding.

Institutional Review Board Statement: The study was conducted according to approval by the Ethics Committee of King Faisal University (KFU-REC/2021-06-19).

Informed Consent Statement: Informed consent was obtained from all subjects involved in the study.

Data Availability Statement: New data have been generated for this study and are not available due to privacy issues.

Conflicts of Interest: The authors declare no conflict of interest. 


\section{Appendix A}

Table A1. The survey questionnaire for the investigation of student intentions to use $\mathrm{DEP}_{\mathrm{s}}$.

The First Section: Demographical Characteristics

Gender:
A. Male:
B. Female:
Age
A. Less than 20 years old
B. $20-25$
C. $26-30$
D. More than 30 years old

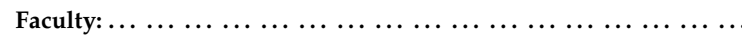

Academic major: ............................

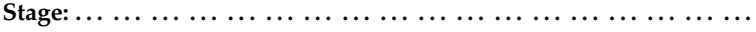

Different kind of $\operatorname{DEP}_{\mathrm{s}}$ that you are using it:

A. Teams

B. Zoom

D. Both

C. Other, please mention it: ... . . . . . . . . . . .

\begin{tabular}{|c|c|c|c|c|c|c|c|}
\hline \multicolumn{8}{|c|}{$\begin{array}{l}\text { The second section: The } 5 \text {-point Likert Scale } \\
\text { Strongly disagree }=1 \\
\text { Disagree }=2 \\
\text { Neutral }=3 \\
\text { Agree }=4 \\
\text { Strongly agree }=5\end{array}$} \\
\hline 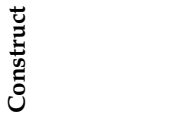 & 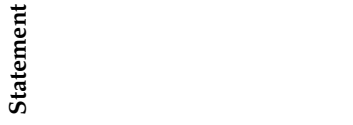 & 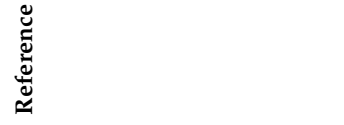 & $r$ & $N$ & $\infty$ & 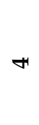 & 10 \\
\hline \multicolumn{8}{|c|}{$\begin{array}{l}\text { Observational Learning } \\
\text { At the } \mathrm{DEP}_{\mathrm{s}} \text {. }\end{array}$} \\
\hline $\begin{array}{l}\text { Observational } \\
\text { Learning } 1\end{array}$ & $\begin{array}{l}\text { I prefer to review an ideal } \\
\text { model to consider during my } \\
\text { learning process and for } \\
\text { accomplishing the assignments } \\
\text { as well. }\end{array}$ & \multirow[t]{6}{*}{$\begin{array}{c}\text { Bandura and McClelland } \\
\text { (1977), } \\
\text { Bandura, (1978), and Bandura } \\
\text { (1985) }\end{array}$} & & & & & \\
\hline $\begin{array}{l}\text { Observational } \\
\text { Learning } 2\end{array}$ & $\begin{array}{l}\text { I apply the entire steps for the } \\
\text { ideal model during my } \\
\text { learning process and for } \\
\text { accomplishing the assignments } \\
\text { as well. }\end{array}$ & & & & & & \\
\hline $\begin{array}{l}\text { Observational } \\
\text { Learning } 3\end{array}$ & $\begin{array}{l}\text { I elect some steps from the } \\
\text { ideal model and input my } \\
\text { specific views during my } \\
\text { learning process and while } \\
\text { accomplishing the assignments } \\
\text { as well. }\end{array}$ & & & & & & \\
\hline $\begin{array}{l}\text { Observational } \\
\text { Learning } 4\end{array}$ & $\begin{array}{l}\text { I prefer to reinforce my } \\
\text { performance immediately or } \\
\text { later on. }\end{array}$ & & & & & & \\
\hline $\begin{array}{l}\text { Observational } \\
\text { Learning } 5\end{array}$ & $\begin{array}{l}\text { Regardless of the } \\
\text { reinforcement of my } \\
\text { performance, I consider the } \\
\text { ideal model during my } \\
\text { learning process and while } \\
\text { accomplishing the } \\
\text { assignments. }\end{array}$ & & & & & & \\
\hline $\begin{array}{l}\text { Observational } \\
\text { Learning } 7\end{array}$ & $\begin{array}{l}\text { Good content design } \\
\text { encourages me to accomplish } \\
\text { my learning process. }\end{array}$ & & & & & & \\
\hline
\end{tabular}


Table A1. Cont.

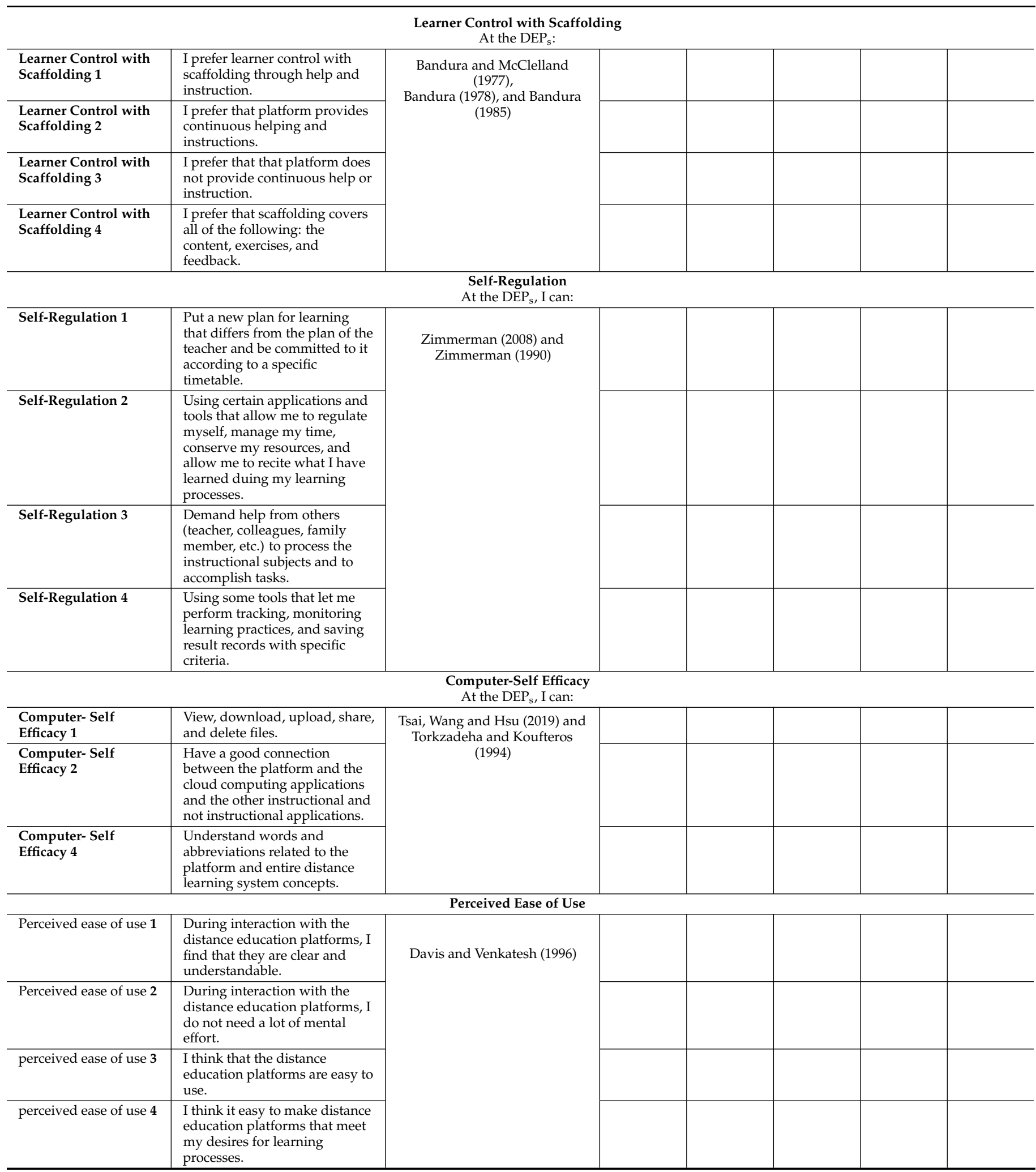


Table A1. Cont.

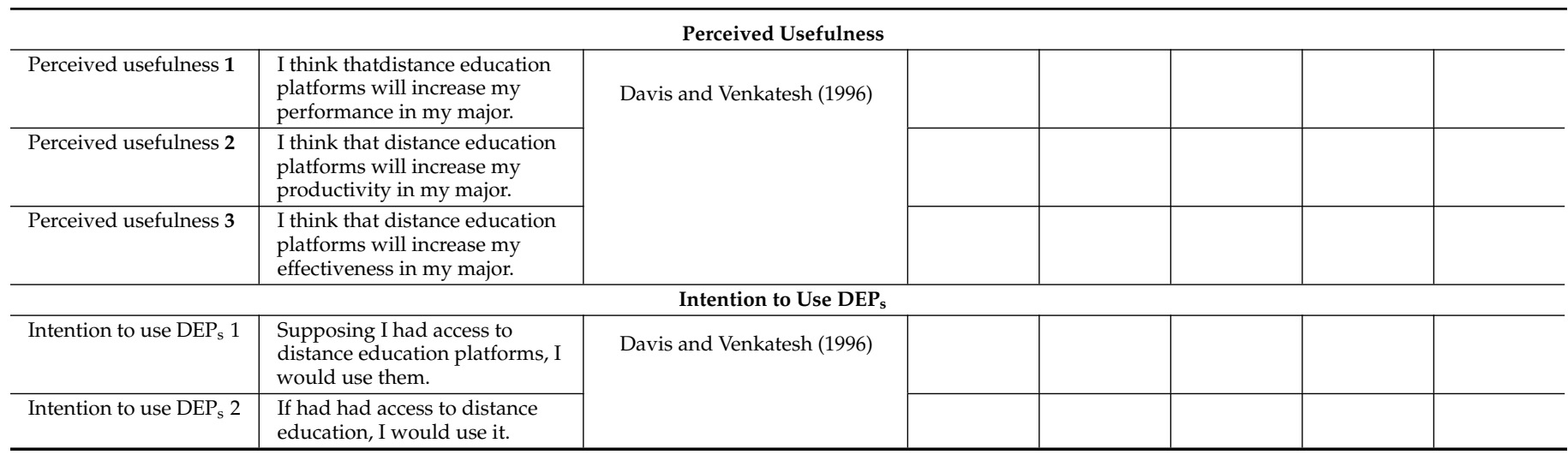

\section{References}

1. Tarasov, A.F.; Getman, I.A.; Turlakova, S.S.; Stashkevych, I.I.; Kozmenko, S.M. Methodological aspects of preparation of educational content on the basis of distance education platforms. CEUR-WS.org 2020, 2643, 161-173.

2. Sahin, I.; Shelley, M. Considering students' perceptions: The distance education student satisfaction model. J. Educ. Techno. Soc. 2008, 11, 216-223.

3. Maor, D. The teacher's role in developing interaction and reflection in an online learning community. EMI Educ. Media Int. 2003, 40, 127-138. [CrossRef]

4. Pymm, B.; Lyn, H. Using etherpads as platforms for collaborative learning in a distance education LIS course. J. Educ. Libr. 2014, 55, 133-149.

5. Ried, L.D.; Byers, K. Comparison of two lecture delivery platforms in a hybrid distance education program. Am. J. Pharm. Educ. 2009, 73, 1-10. [CrossRef]

6. Liu, Z.Y.; Lomovtseva, N.; Korobeynikova, E. Online learning platforms: Reconstructing modern higher education. iJET 2020, 15, 4-21. [CrossRef]

7. Eldokny, A.A.; Drwish, A.M. Effectiveness of augmented reality in online distance learning at the time of the COVID-19 pandemic. iJET 2021, 16, 198-218. [CrossRef]

8. Al-Rahmi, W.M.; Othman, M.S.; Yusuf, L.M. Using social media for research: The role of interactivity, collaborative learning, and engagement on the performance of students in Malaysian post-secondary institutes. Medit. J. Soc. Sci. 2015, 6, 536-546. [CrossRef]

9. Al-Rahmi, W.M.; Yahaya, N.; Aldraiweesh, A.A.; Alamri, M.A.; Aljarboa, N.A.; Alturki, U.; Aljeraiwi, A.A. Integrating technology acceptance model with innovation diffusion theory: An empirical investigation on students' intention to use e-learning systems. IEEE Access 2019, 7, 26797-26809. [CrossRef]

10. Mohammadi, H. Investigating users' perspectives on e-learning: An integration of TAM and IS success model. Comput. Hum. Behav. 2015, 45, 359-374. [CrossRef]

11. Almaiah, M.A.; Al-Khasawneh, A.; Althunibat, A. Exploring the critical challenges and factors influencing the E-learning system usage during COVID-19 pandemic. Educ. Inf. Technol. 2020, 25, 5261-5280. [CrossRef] [PubMed]

12. Chu, T.-H.; Chen, Y.-Y. With good we become good: Understanding e-learning adoption by theory of planned behavior and group influences. Comput. Educ. 2016, 92, 37-52. [CrossRef]

13. Erichsen, E.A.; Bolliger, D.U.; Halupa, C. Student satisfaction with graduate supervision in doctoral programs primarily delivered in distance education settings. Stud. High. Educ. 2014, 39, 321-338. [CrossRef]

14. Almaiah, M.A.; Alyoussef, I.Y. Analysis of the effect of course design, course content support, course assessment and instructor characteristics on the actual use of E-learning system. IEEE Access 2019, 28, 171907-171922. [CrossRef]

15. Ibrahim, R.; Leng, N.S.; Yusoff, R.C.M.; Samy, G.N.; Masrom, S.; Rizman, Z.I. E-learning acceptance based on technology acceptance model (TAM). J. Fundam. Appl. Sci. 2017, 9, 871-889. [CrossRef]

16. Davis, F.D.; Venkatesh, V. A critical assessment of potential measurement biases in the technology acceptance model: Three experiments. Int. J. Hum. Comput. 1996, 45, 19-45. [CrossRef]

17. Davis, F.D.; Bagozzi, R.P.; Warshaw, P. User acceptance of computer technology: A comparison of two theoretical models. Manag. Sci. 1989, 35, 982-1003. [CrossRef]

18. Almaiah, M.A. Acceptance and usage of a mobile information system services in University of Jordan. Educ. Inf. Technol. 2018, 23, 1873-1895. [CrossRef]

19. Alamri, M.M.; Almaiah, M.A.; Al-Rahmi, W.M. The role of compatibility and task-technology fit (TTF): On social networking applications (SNAs) usage as sustainability in higher education. IEEE Access 2020, 8, 6471-6485. [CrossRef]

20. Almaiah, M.A.; Almulhem, A.A. Conceptual framework for determining the success factors of e-learning system implementation using Delphi technique. J. Theor. Appl. Inf. Technol. 2018, 24, 5962-5976. [CrossRef] 
21. Bandura, A. Social-learning theory of identificatory processes. In Handbook of Socialization Theory and Research; Goslin, D.A., Ed.; Randy McNally \& Company: Chicago, IL, USA, 1969; pp. 213-261.

22. McCullagh, P. Model status as a determinant of observational learning and performance. J. Sport Exerc. Psychol. 1986, 8, 319-331. [CrossRef]

23. Bandura, A.; Walters, R.H. Social Learning and Personality Development; Holt Rinehart and Winston: New York, NY, USA, 1963.

24. Bandura, A. Social Foundations of Thought and Action: A Social Cognitive Theory; Prentice-Hall: Englewood Cliffs, NJ, USA, 1986; pp. 399-409.

25. Bandura, A.; Cervone, D. Self-evaluative and self-efficacy mechanisms governing the motivational effects of goal systems. J. Pers. Soc. Psychol. 1983, 45, 1017-1102. [CrossRef]

26. Cervone, D.; Peake, P.K. Anchoring, efficacy, and action: The influence of judgmental heuristics on self-efficacy judgments and behavior. J. Pers. Soc. Psychol. 1986, 50, 492-501. [CrossRef]

27. Jacobs, B.; Prentice-Dunn, S.; Rogers, R.W. Understanding persistence: An interface of control theory and self-efficacy theory. BASP 1984, 5, 333-347. [CrossRef]

28. Weinberg, R.S.; Gould, D.; Jackson, A. Expectations and performance: An empirical test of Bandura's self-efficacy theory. J. Sport Psychol. 1979, 1, 320-331. [CrossRef]

29. Zimmerman, B.J. Self-regulated learning and academic achievement: An overview. Educ. Psychol. 1990, 25, 3-17. [CrossRef]

30. Bandura, A. Social cognitive theory of self-regulation. Organ. Behav. Hum. Decis. Process. 1991, 50, 248-287. [CrossRef]

31. Bandura, A. Self-regulation of motivation and action through goal systems. In Cognitive Perspectives on Emotion and Motivation; Hamilton, V., Ed.; Springer: Dordrecht, The Netherlands, 1988; pp. 37-61. [CrossRef]

32. Zimmerman, B.J. Investigating self-regulation and motivation: Historical background, methodological developments, and future prospects. Am. Educ. Res. J. 2008, 45, 166-183. [CrossRef]

33. Bandura, A. Regulation of cognitive processes through perceived self-efficacy. Dev. Psychol. 1989, 25, 729. [CrossRef]

34. Gist, M.E.; Mitchell, T.R. Self-efficacy: A theoretical analysis of its determinants and malleability. Acad. Manag. Rev. 1992, 17, 183-211. [CrossRef]

35. Gist, M.E.; Schwoerer, C.; Rosen, B. Effects of alternative training methods on self-efficacy and performance in computer software training. J. Appl. Psychol. 1989, 74, 884. [CrossRef]

36. Bandura, A. Guide for constructing self-efficacy scales. In Self-Efficacy Beliefs of Adolescents; Information Age Publishing: Greenwich, UK, 2006; pp. 307-337.

37. Hill, T.; Smith, N.D.; Mann, M.F. Role of efficacy expectations in predicting the decision to use advanced technologies: The case of computers. J. Appl. Psychol. 1987, 72, 307-313. [CrossRef]

38. Murphy, C.A.; Coover, D.; Owen, S.V. Development and validation of the computer self-efficacy scale. Educ. Psychol. Meas 1989, 49, 893-899. [CrossRef]

39. Davis, F.D. Technology Acceptance Model for Empirically Testing New End-User Information Systems: Theory and Results. Ph.D. Thesis, Massachussetts Institute of Technology, Massachusetts, MA, USA, 20 December 1986.

40. Davis, F.D. User acceptance of information technology: System characteristics, user perceptions and behavioral impacts. Int. J. Man Mach. Stud. 1993, 38, 475-487. [CrossRef]

41. Davis, F.D. Perceived usefulness, perceived ease of use, and user acceptance of information technology. MIS Q. 1989, 13, 319-340 [CrossRef]

42. Bandura, A.; Freeman, W.H.; Lightsey, R. Self-efficacy: The exercise of control. J. Cogn. Psychother. 1999, 13, 158-166. [CrossRef]

43. Fani, T.; Ghaemi, F. Implications of Vygotsky's zone of proximal development (ZPD) in teacher education: ZPTD and selfscaffolding. Procedia Soc. Behav. Sci. 2011, 29, 1549-1554. [CrossRef]

44. Nordlof, J. Vygotsky, scaffolding, and the role of theory in writing center work. WCJ 2014, 1, $45-64$.

45. Van Der Stuyf, R.R. Scaffolding as a teaching strategy. Adolesc. Learn. Dev. 2002, 52, 5-18.

46. Tuckman, B.W. The effect of motivational scaffolding on procrastinators' distance learning outcomes. Comput. Educ. 2007, 49, 414-422. [CrossRef]

47. Ozlem, O.Z.A.N. Scaffolding in connectivist mobile learning environment. Turk. Online J. Distance Educ. 2013, $14,44-55$.

48. McLoughlin, C. Learner support in distance and networked learning environments: Ten dimensions for successful design. Distance Educ. 2002, 23, 149-162. [CrossRef]

49. Zimmerman, B.J. Developing self-fulfilling cycles of academic regulation: An analysis of exemplary instructional models. In Self-Regulated Learning: From Teaching to Self-Reflective Practice; Schunk, D.H., Zimmerman, B.J., Eds.; Guilford Press: New York, NY, USA, 1998; pp. 1-19.

50. Williams, P.E.; Hellman, C.M. Differences in self-regulation for online learning between first- and second-generation college students. Res. High. Educ. 2004, 45, 71-82. [CrossRef]

51. Purdie, N.; Hattie, J.; Douglas, G. Student conceptions of learning and their use of self-regulated learning strategies: A crosscultural comparison. J. Educ. Psychol. 1996, 88, 87. [CrossRef]

52. Tsai, I.C.; Tung, I.C.; Laffey, J. Exploring how students' self-regulated learning influences the social nature of online learning. In An Annual Meeting of the American Educational Research Association; New York, NY, USA, 2008. Available online: https:/ / www.semanticscholar.org/paper/Exploring-How-Students\%27-Self-regulated-Learning-the-Tsai / 6c4079713a46d961 b343a504e0e1dc74e02d9824 (accessed on 20 November 2021). 
53. Tabak, F.; Nguyen, N.T. Technology acceptance and performance in online learning environments: Impact of self-regulation. Technology 2013, 9, 116-130.

54. Williams, J.E.; Hellman, C.M. Investigating self-regulated learning among first-generation community college students. J. Appl. Res. Community Coll. 1998, 5, 83-87.

55. Bandura, A. Self-efficacy: Toward a unifying theory of behavioral change. Psychol. Rev. 1977, 84, 191-215. [CrossRef]

56. Compeau, D.R.; Higgins, C.A. Computer self-efficacy: Development of a measure and initial test. MIS Q. 1995, 19, 189-211. [CrossRef]

57. Kukul, V.; Gökçearslan, Ş.; Günbatar, M.S. Computer programming self-efficacy scale (CPSES) for secondary school students: Development, validation and reliability. Eğitim Teknol. Kuram Ve Uygul. 2017, 7, 158-179. [CrossRef]

58. Tsai, M.J.; Wang, C.Y.; Hsu, P.F. Developing the computer programming self-efficacy scale for computer literacy education. J. Educ. Comput. Res. 2019, 56, 1345-1360. [CrossRef]

59. Ramalingam, V.; LaBelle, D.; Wiedenbeck, S. Self-efficacy and mental models in learning to program. Presented at the Ninth Annual SIGCSE Conference on Innovation and Technology in Computer Science Education (ITiCSE), Leeds, UK, 28 June 2004.

60. Ramalingam, V.; Wiedenbeck, S. Development and validation of scores on a computer programming self-efficacy scale and group analyses of novice programmer self-efficacy. J. Educ. Comput. Res. 1988, 19, 367-381. [CrossRef]

61. Moos, D.C.; Azevedo, R. Learning with computer-based learning environments: A literature review of computer self-efficacy. Rev. Educ. Res. 2009, 79, 576-600. [CrossRef]

62. Lee, M.K.; Cheung, C.M.; Chen, Z. Acceptance of Internet-based learning medium: The role of extrinsic and intrinsic motivation. Inf. Manag. 2005, 42, 1095-1104. [CrossRef]

63. Ngai, E.W.T.; Poon, J.K.L.; Chan, Y.H.C. Empirical examination of the adoption of WebCT using TAM. Comput. Educ. 2007, 48, 250-267. [CrossRef]

64. Liaw, S.S.; Huang, H.M. Perceived satisfaction, perceived usefulness, and interactive learning environments as predictors to self-regulation in e-learning environments. Comput. Educ. 2013, 60, 14-24. [CrossRef]

65. Lee, Y.H.; Hsieh, Y.C.; Hsu, C.N. Adding innovation diffusion theory to the technology acceptance model: Supporting employees' intentions to use e-learning systems. J. Educ. Technol. Soc. 2011, 14, 124-137.

66. Landry, B.J.; Griffeth, R.; Hartman, S. Measuring student perceptions of blackboard using the technology acceptance model. Decis. Sci. J. Innov. Educ. 2006, 4, 87-99. [CrossRef]

67. Alharbi, S.; Drew, S. Using the technology acceptance model in understanding academics' behavioural intention to use learning management systems. Int. J. Adv. Comput. Sci. Appl. 2014, 5, 143-155. [CrossRef]

68. Al-Ammary, J.H.; Al-Sherooqi, A.K.; Al-Sherooqi, H.K. The acceptance of social networking as a learning tool at University of Bahrain. J. Inf. Educ. 2014, 4, 208. [CrossRef]

69. Al-Rahmi, W.M.; Alias, N.; Othman, M.S.; Alzahrani, A.I.; Alfarraj, O.; Saged, A.A.; Rahman, N.S.A. Use of e-learning by university students in Malaysian higher educational institutions: A case in Universiti Teknologi Malaysia. IEEE Access 2018, 6, 14268-14276. [CrossRef]

70. Hamid, H.E.A. Advanced Statistics for Educational, Psychological and Social Sciences; Dar Al-Fikr Al-Arabi: Cairo, Egypt, 2016; pp. 15-576.

71. Hu, L.-T.; Bentler, P.M. Evaluating model fit. In Structural Equation Modeling: Concepts, Issues, and Applications; Hoyle, R.H., Ed.; Sage Publications, Inc.: Washington, DC, USA, 1995; pp. 76-99.

72. Byrne, B.M. Structural Equation Modeling with AMOS: Basic Concepts, Applications, and Programming, 2nd ed.; Routledge: New York, NY, USA, 2010.

73. Kline, R. Principles and Practice of Structural Equation Modeling, 3rd ed.; The Guilford Press: New York, NY, USA, 2011.

74. Hair, J.F.; Sarstedt, M.; Ringle, C.M.; Mena, J.A. An assessment of the use of partial least squares structural equation modeling in marketing. Res. J. Acad. Mark. Sci. 2012, 40, 414-433. [CrossRef]

75. Fornell, C.; Larcker, D.F. Evaluating structural equation models with unobservable variables and measurement error. J. Mark. Res. 1981, 18, 39-50. [CrossRef]

76. Venkatesh, V.; Davis, F.D. A theoretical extension of the technology acceptance model: Four longitudinal field studies. Manag. Sci. 2000, 46, 186-204. [CrossRef]

77. Venkatesh, V.; Morris, M.; Davis, G.; Davis, F.D. User acceptance of information technology: Toward a unified view. MIS Q. 2003, 27, 425-478. [CrossRef]

78. Masrom, M. Technology acceptance model and e-learning. Technology 2007, 21, 216-223.

79. Baharin, A.T.; Lateh, H.; Nathan, S.S.; Mohd Nawawi, H. Evaluating effectiveness of IDEWL using technology acceptance model. Procedia. Soc. Behav. Sci. 2015, 171, 897-904. [CrossRef]

80. Alyoussef, I.Y. Massive open online course (MOOCs) acceptance: The role of task-technology fit (TTF) for higher education sustainability. Sustainability 2021, 13, 7374. [CrossRef]

81. Mathieson, K. Predicting user intentions: Comparing the technology acceptance model with the theory of planned behavior. Inf. Syst. Res. 1991, 2, 173-191. [CrossRef]

82. Al Mulhim, E.; Eldokhny, A. The impact of collaborative group size on students' achievement and product quality in project-based learning environments. iJET 2020, 15, 157-174. [CrossRef] 
83. Compeau, D.R.; Higgins, C.A.; Huff, S. Social cognitive theory and individual reactions to computing technology: A longitudinal study. MIS Q. 1999, 23, 145-158. [CrossRef]

84. Bandura, A. Human agency in social cognitive theory. Am Psychol 1989, 44, 1175-1184. [CrossRef]

85. Venkatesh, V. Creation of favorable user perceptions: Exploring the role of intrinsic motivation. MIS Q. 1999, 23, 239-260. [CrossRef]

86. Rezaei, M.; Mohammadi, H.M.; Asadi, A.; Kalantary, K. Predicting e-learning application in agricultural higher education using technology acceptance model. Turk. Online J. Distance Educ. 2008, 9, 85-95.

87. Kelly, H. A path analysis of educator perceptions of open educational resources using the technology acceptance model. IRRODL 2014, 15, 26-42. [CrossRef]

88. Alksasbeh, M.; Abuhelaleh, M.; Almaiah, M.; AL-Jaafreh, M.; Abu karaka, A. Towards a Model of Quality Features for Mobile Social Networks Apps in Learning Environments: An Extended Information System Success Model. iJIM 2019, 13, 75-93. [CrossRef]

89. Ardito, C.; Costabile, M.F.; De Marsico, M.; Lanzilotti, R.; Levialdi, S.; Roselli, T.; Rossano, V. An approach to usability evaluation of e-learning applications. Univers. Access Inf. Soc. 2006, 4, 270-283. [CrossRef]

90. Holsapple, C.W.; Lee-Post, A. Defining, assessing, and promoting e-learning success: An information systems perspective. Decis. Sci. J. Innov. Educ. 2006, 4, 67-85. [CrossRef]

91. Xie, K.; Debacker, T.K.; Ferguson, C. Extending the traditional classroom through online discussion: The role of student motivation. J. Educ. Comput. Res. 2006, 34, 67-89. [CrossRef]

92. Saadé, R.G. Dimensions of perceived usefulness: Toward enhanced assessment. Decis. Sci. J. Innov. Educ. 2007, 5, 289-310. [CrossRef]

93. Mitchell, T.J.F.; Chen, S.Y.; Macredie, R.D. The relationship between web enjoyment and student perceptions and learning using a web-based tutorial. Learn. Media Technol. 2005, 30, 27-40. [CrossRef]

94. Jones, P.; Packham, G.; Miller, C.; Jones, A. An initial evaluation of student withdrawals within an elearning environment: The case of e-college Wales. EJEL 2004, 2, 113-120.

95. Collis, B.; Winnips, K.; Moonen, J. Structured support versus learner choice via the World Wide Web (WWW): Where is the payoff? J. Interact. Learn. Res. 2000, 11, 163-196.

96. Winnips, K. Scaffolding-by-Design: A Model for WWW-Based Learner Support; University of Twente Press: Enschede, The Netherlands, 2000 .

97. Oliver, R.; McLoughlin, C. Using networking tools to support online learning. In Innovation in Open and Distance Learning: Successful Development of Online and E-Web-Based Learning; Lockwood, F., Ed.; Routledge: London, UK, 2001 ; pp. 160-171.

98. Lee, Y.H.; Hsieh, Y.C.; Ma, C.Y. A model of organizational employees' e-learning systems acceptance. Knowl. Based Syst. 2010, 24, 355-366. [CrossRef]

99. Almaiah, M.A. Thematic analysis for classifying the main challenges and factors influencing the successful implementation of e-learning system using NVivo. Int. J. Adv. 2020, 9, 142-152. [CrossRef]

100. Meng, H.J.; Wang, T.Y. Acceptance of IWBs instruction and concomitant behavior through self-regulation learning. JoC 2014, 1, $1-5$. 